\title{
舌下神経の舌血管縮小作用について
}

\author{
関西医科大学生理学教室 \\ 幸塚 嘉一, 内藤 博江, 浅井茂次, 堀川 惺子
}

\section{On Vasoconstricting Actions of Hypoglossal Nerves}

Kaichi Kotsuka, Hiroe Naito, Shigeji Asai, Shizuka Horikawa

Department of Physiology, Kansai Medical School

1. Blood vessels in a bull-frog's tongue are constricted when the cut peripheral end of hypoglossal nerves is stimulated with a new "glycerine spot method" and mechanical stimulation method. It is evidenced that there exist the efferent hypoglossal vasoconstricting nerves in a bull-frog's tongue.

Hypoglossal nerves have been classically believed to be pure somatomotor nerves in the cerebral nerves. But it is demonstrated in the present experiment that vasoconstricting nerves which are visceromotoric exist in the hypoglossal nerves in a bull-frog.

2. Pertaining to a bull-frog, hypoglossal nerves are equivalent in terms of vasomotoric function to the anterior root of spinal nerves.

舌下神経は元来純 somatomotor の神経であると考え られて来た. Krogh (1919) はカエルの舌下神経の電気 的刺激に上つて舌血管に何等の変化も認》得なかつたと 報告し，又銭場（1949）むカェルについて同様な結果を 得ている. しかし是等はいずれもクラーレ麻醉を施した カエルについておこなつた実験であるから，自律神経線 維がクラーレによつて何等障碍されていないという確証 がない限りは, 是等の成績に賛成することは出来ない. 又 Krogh $(1919,1930)$ に上れば，舌血管は Bayliss の antidromic type の axon reflex によつて反応するとな し，舌に対する自律神経支配を否定している。しかし銭 場は舌えの遠心性神経線維の存在の主張により舌血管の 反応を説明し，Krogh のいう軸索反射について疑問を 明示した. とてろが最近中西教室においては，ガの舌 下神経中に自律神経線維が存在するととを，オスミウム 酸に上る特殊染色法に上つて組織学的に実証し，之に上 つて舌の自律神経支配が明かとなつたのである。

さて本研究においては，更江舌下神経中に血管进動神 経として遠心性の舌血管縮少神経線維が含まれているこ とを，生理学的実験により実証しえたので報告する.

\section{实 确方法}

食用カエルを使用した、エーテル麻醉下にて実験をお こなう.
舌下神経の刺激に当つては，あらかじめ背側より頭蓋 腔を開いて延䜔を露出し, 舌下神経の延铕からの起始根 部を延咀に接して切断する。てての舌下神経の末梢切断端 を, 頭蓋腔内にて 新研究方法 "グリセリン点隹法” (glycerine spot method，1952 幸冢）により刺激した (図1).

舌血管としては，主としてその小動脈乃至細動脈につ いて検した. 舌血管の観祭方鈌は，前報と同㥞に Langley の淮奖する方法によつた。 即透射光の下で顕微鏡 下 $(10 \times 10)$ オクラールマイクロメーター $(1 / 10 \mathrm{~mm})$ にて血管直径の変化を測定した. 又連続䫓徽鏡写真の掫 影もおこなつた。尚本実験は 9 月一12月の期間中におこ なつた。

\section{実験成䋨および考察}

前行の如き栖本について，舌下神経の末梢切断端を頭

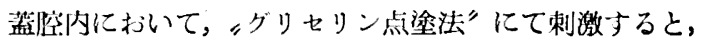
舌血管は舌下神経刺激㓣に比して縮小を示した。即血管 直径注著明なる減少を示し, 血流は綏徐となり, 血球密 度は疎となつた。しかしとの血管縮小は一定時間の後元 の状態に回復した。困 2 は舌血管の顕微鏡写真像で，図 2 a は舌下神経刺激脚の舌血篦を示す. 図 2 b は舌下神

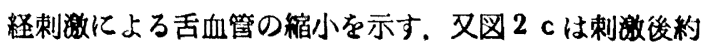
$6^{\prime}$ 経過後の血管で，縮小は稍々回復を示している，ての 


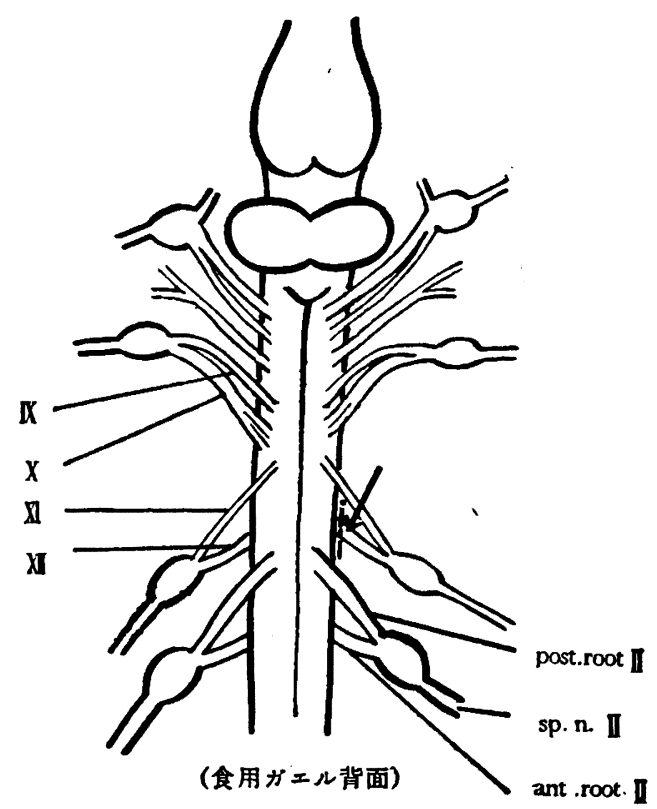

図1XI：舌下神経

X：副神経

X：迷走神経

X : 舌咽神経

post. root I：後根 I

sp. n. I：第 2 脊咀神経

ant. root I：前根 I

- - - : 舌下神経切断

๘：舌下神経末佾切断端を刺激

舌下神経刺激による舌血管縮小変化の時間的経過である が，潜刺激時としては舌下神経に刺激を加えてより本実 験方法にて測定し得る变化が現れはじめるまでの時間が 平均10"一15”であり，血管が最も縮小を示したのは 2 前 後であつた. そして4'-10後には大体元の状態に回復し た，表 1 は代表的な 1 例について，舌下神経刺激による 舌血管縮小変化の時間経過を示す. 又表 2 は代表的な実 験例10例について，舌下神経刺激による舌血管直径の変 化を示す. 即舌血管は, 舌下神経の刺激によつて刺激前 の血管直径に比して平均約33\%の縮小を示した。

以上の成績から舌下神経が舌血管に対して血管縮小作 用を有するととが明かである，且本実験においては，舌 下神経起始根部において舌下神経の未梢切断端を刺激し たのであるから，Krogh のいう如き reflex の影制は一 切考えられず舌下神経中には遠心性の血算縮小神経線維 が存在するととが明かである。

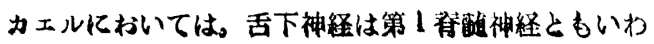

第 1 婁 舌下神経の舌血管編小作用

(・グリャリン点塗法”による)

\begin{tabular}{|c|c|c|}
\hline \multicolumn{2}{|c|}{ 操作打よび時間経過 } & 舌血管值径 \\
\hline \multicolumn{2}{|c|}{$\begin{array}{c}\text { 舌下神経を延醚より離断 } \\
\text { (約20分間静㯰) }\end{array}$} & \\
\hline \multicolumn{2}{|c|}{ 刺激首 $5^{\prime}$} & 5.0 \\
\hline \multicolumn{2}{|l|}{$\prime \prime$} & 5.0 \\
\hline \multicolumn{2}{|l|}{$\prime \prime$} & 5.0 \\
\hline \multicolumn{2}{|c|}{$" 1$} & 5.0 \\
\hline \multicolumn{3}{|c|}{$\begin{array}{l}\text { 舌下神経末梢切断端に Glycerin } \\
\text { spot 加 }\end{array}$} \\
\hline \multicolumn{2}{|c|}{ (Glycerine spot 加後) 15" } & 4.0 \\
\hline$\prime \prime$ & ) $30 "$ & 4.0 \\
\hline( & ) $1^{\prime}$ & 4.0 \\
\hline( & $2^{\prime}$ & 3.0 \\
\hline( & $3^{\prime}$ & 3.5 \\
\hline( & $4^{\prime}$ & 4.0 \\
\hline( & $5^{\prime}$ & 5.0 \\
\hline( & $6^{\prime}$ & 5.0 \\
\hline( & $7^{\prime}$ & 5.0 \\
\hline( & $8^{\prime}$ & 5.0 \\
\hline
\end{tabular}

（食用ガエル，早体重 $86 \mathrm{~g}$ ，脂肪体 $1.5 \mathrm{~g}$ ）

第 2 妻 舌下神経の舌血管縮小作用

\begin{tabular}{|c|c|c|c|c|c|}
\hline \multirow{2}{*}{ 番号 } & \multicolumn{3}{|c|}{ 食用ガエル } & \multirow{2}{*}{$\begin{array}{l}\text { 舌下神経刺激によ } \\
\text { 乃舌血管直径の変 } \\
\text { 华 } \\
\text { 刺激前—刺激下 }\end{array}$} & \multirow{2}{*}{\begin{tabular}{|c|} 
血管縮小率 \\
$(\%)$
\end{tabular}} \\
\hline & 性 & $\begin{array}{l}\text { 体重 } \\
(\mathbf{g})\end{array}$ & $\mid \begin{array}{c}\text { 脂肪体 } \\
(\mathbf{g})\end{array}$ & & \\
\hline 1 & 占 & 95 & 2.0 & $4.0 \longrightarrow 2.0$ & $50.0 \%$ \\
\hline 2 & 今 & 83 & 1.0 & $5.0 \longrightarrow 3.0$ & $40.0 \%$ \\
\hline 3 & 우 & 62 & 1.7 & $7.5 \longrightarrow 4.0$ & $46.7 \%$ \\
\hline 4 & 우 & 76 & 2.8 & $6.0 \longrightarrow 2.0$ & $66.6 \%$ \\
\hline 5 & 今 & 112 & 1.5 & $5.0 \longrightarrow 4.0$ & $20.0 \%$ \\
\hline 6 & $\hat{\delta}$ & 85 & 0.7 & $8.0 \longrightarrow 7.0$ & $12.5 \%$ \\
\hline 7 & ô & 90 & 1.7 & $8.0 \longrightarrow 7.0$ & $12.5 \%$ \\
\hline 8 & 今 & 103 & 1.0 & $5.0 \longrightarrow 4.0$ & $20.0 \%$ \\
\hline 9 & 우 & 65 & 0.1 & $4.0 \longrightarrow 3.0$ & $25.0 \%$ \\
\hline 10 & 우 & 86 & 1.5 & $5.0 \longrightarrow 3.0$ & $40.0 \%$ \\
\hline
\end{tabular}

れ人によつては之を睬神経から除外して考えている様で ある、この観点からみるならば，舌下神経の起始根は延

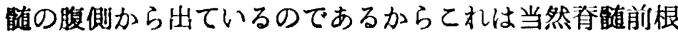
と equivalent の存在として考えられるのである. 又脊 蹃前根中には周知の如く交感神経(Langley) 性の血管縮 小神経線維が存在するのであつて，当教室においてはさ

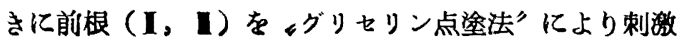
して舌血管の縮小を確認した。従つて本実䓉において舌 下神経の舌血然躍小作用を実証し得たということは。舌 

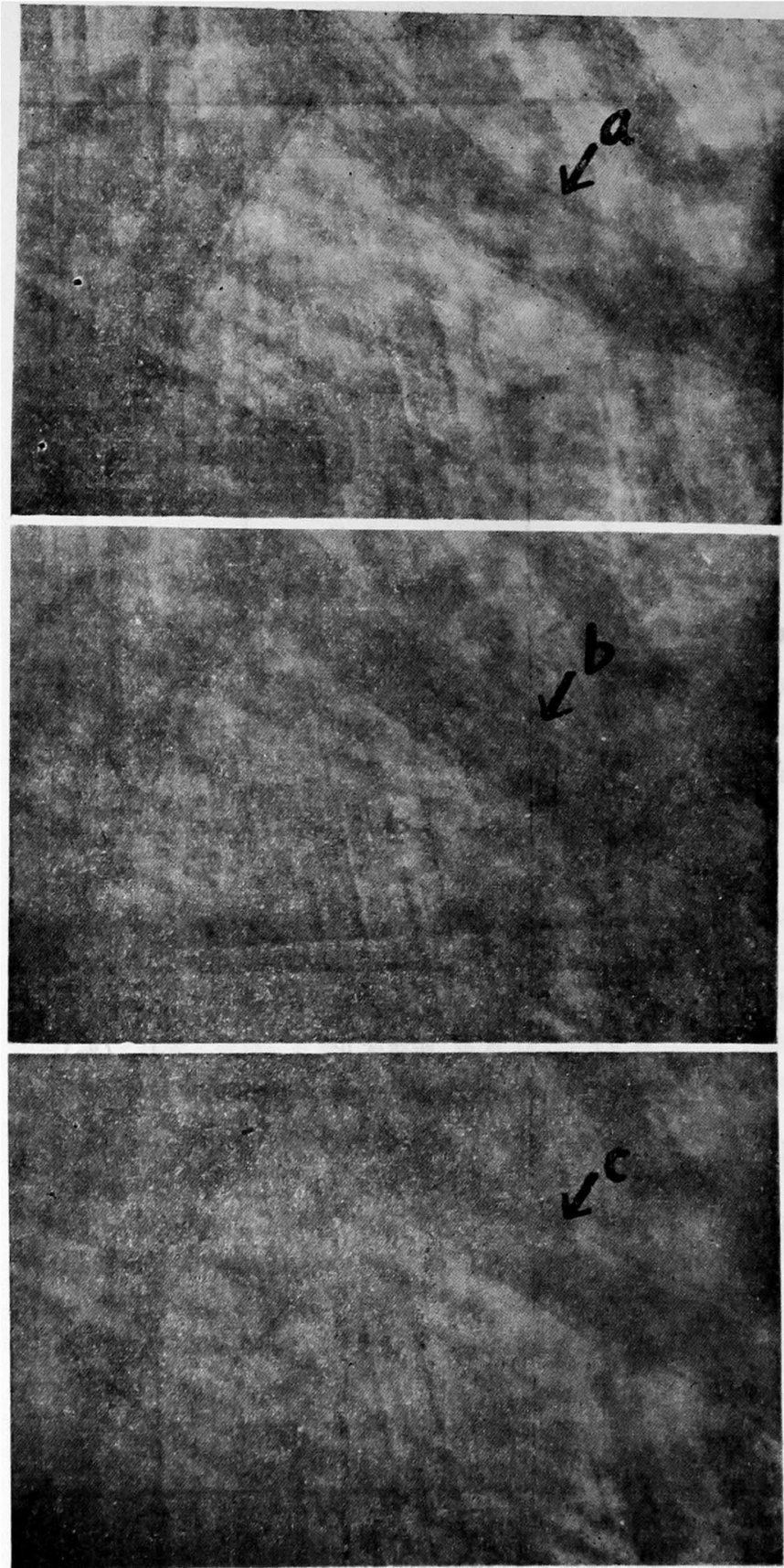

図 2 a : 舌下神経刺激前の舌血管

b : 舌下神経刺激により血管緹小を示す

c：刺激後約 6 経過後の同血管

神経性血管拡張神経，迷走神経性血管縮小 神経, 舌咽神経性血管拡張神経および舌咽 神経性血管縮小神経の存在を明かになし得 たのであるが，本研究においては更に従来 純 somatomotor と考えられていたとてろ の舌下神経中に visceromotor fibre として の舌血管縮小神経線維が存在するととを実 証しえたわけである．尚温血動物の舌下神 経については後日を期す.

\section{結}

1）食用ガエルについて, 舌下神経の起 始根部におけるその未梢切断端を，新研究 方法 “グりセりン点塗法”にて刺激するて とにより，舌血管の縮小を証明した。 之に よつて舌下神経中には遠心性の舌血管縮小 神経線維が存在することが明かである.

従つて従来純 somatomotor と考えられ ていたところの脳神経としての舌下神経中 そ, visceromotor fibre としての血管縮小 神経線維が存在するととを実証しえたわけ である.

2）舌下神経 はその 血管運動性の機能 上, 脊賄前根と equivalent であるとい〉 うる.

本研究は日本ワックスマン財団研究助成

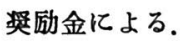

本論文の要旨は第 129 回生理学東京談話 会に打いて発表した。

文献

1) Goupp, E. : A. Ecker's und R. Wiedersheim's Anatomie des Frosches. 1896.

2) Bayliss, W.M. : J. Physiol. $26: 173$, 1901.

3) Krogh, A. : J. Physiol. $53:$ 339, 1919.

4) Krogh, A.: The Anatomy and Physiology of Capillaries : 123, 1930.

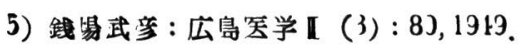

下神経が春榷前根と equivalent であるとする解剖的関 係に correspond するところの機能的な実験結果を得た わけである。

さきに私たちは脑神経中の血管運動神経として，迷走
6）銭場武产：広島医学】(4): 113，1949.

7) 幸塚芘一,内藤博江：医学々生物学. 45 (3): 99, 1957.

8）莘塚喜一, 内藤博近: 医学々生物学、 $45(5): 210$, 
第11巻第 1 号 1959

1957.

9）幸塚嘉一, 内藤博江：医学と生物学. 46 (1):20, 1958.

10）中西政周：骨絡筋の拮抗性交感神経司配. 110 , 永 井書店. 1958 .
11）中西政䧓，西中弘：第18回近譏生理学談話会にて発 表. 1958 .

12）幸塚嘉一，堀川惺子：第19回近畿生理学談話会に於 て発表. 